\title{
Nærvær
}

\section{- forsøg på en nem definition af leg}

Af Jørn Møller

\section{Fanomenologisk antropologi}

Ordet »maya« betyder på sanskrit på én gang »leg «, »magi « og det »at finde verden « eller »at skabe verden $« .{ }^{1}$

Leg vedrører med andre ord menneskers tilgang til verden som fænomen, og store filosoffer fra Platon ${ }^{2}$ til Nietzsche ${ }^{3}$ og Wittgenstein ${ }^{4}$ har i deres overvejelser over tilværelsens fundament og erkendelsens vilkår gang på gang set sig henvist til at skulle tage stilling til legens kategori. I H.-G. Gadamers »filosofiske hermeneutik « er leg således den nøglekategori, ${ }^{5}$ der bringer mennesker til forståelse af verden og til indbyrdes forståelse. Forståelse bliver dermed ikke blot et sprogligt, men også et kropsligt projekt, og legens placering forskydes fra en pædagogisk funktionel til en basalt eksistentiel sammenhæng. Dette bliver udgangspunktet for en række kontinentale forskere, som i mellemkrigstiden bidrager til en skole, som benævnes fænomenologisk antropologi. ${ }^{6}$ Dens forudsætninger ligger i eksistentialismen og hermeneutikken, og til dens medlemmer kan blandt andre henregnes V. v. Weitzäcker, Helmuth Plessner, F.J.J. Buytendijk, J. Huizinga og Husserls nære medarbejder Eugen Fink.

Gruppens værker er ikke nemt tilgængelige, og alligevel er dele af det, de fremfører, blevet selvfølgeligheder inden for kulturforskningen. Fælles for dem er afvisningen af det absolutte skel mellem subjekt og objekt og dermed af muligheden for at kunne forklare levende menneskers adfærd med naturvidenskabelige metoder. Mennesket er placeret situationelt og intentionelt $i$ forhold til sine omgivelser, og det samme gælder naturligvis forskeren i sin omgang med mennesker i den kultur, der udforskes. Det betyder, at empirisk beskrivelse, som isolerer et endeligt antal faktorer, kommer til kort over for helhedens dynamiske og relationelle totalitet. De ydre rammer udgør en kompliceret flerdimensionel horisont for en given adfærd, men aldrig en årsag i naturvidenskabelig forstand. I forskellige horisonter gives altid forskellige grader af rum for subjektive handlinger, som er principielt uforudsigelige og kan udspille sig i konformitet med horisonten eller anfægte og overskride den. Det er den subjektive intentionalitet $\mathrm{i}$ disse handlinger, som tilfører situationen dens mening, og det betyder, at forskeren - afskåret fra kausalt udtømmende forklaringer - nødvendigvis må søge en forståelse af denne mening gennem analyse og fremlæggelse af situationen, dens indre logik og individernes relationelle positioneringer og intentioner.

Sagt på en anden måde: Hvis man sparker til en sten, vil resultatet kunne beskrives $i$ henhold til fysiske love om den anvendte energi, sparkets retning og materialernes beskaffenhed. Sparker man til en hund, vil hunden reagere efter de samme 


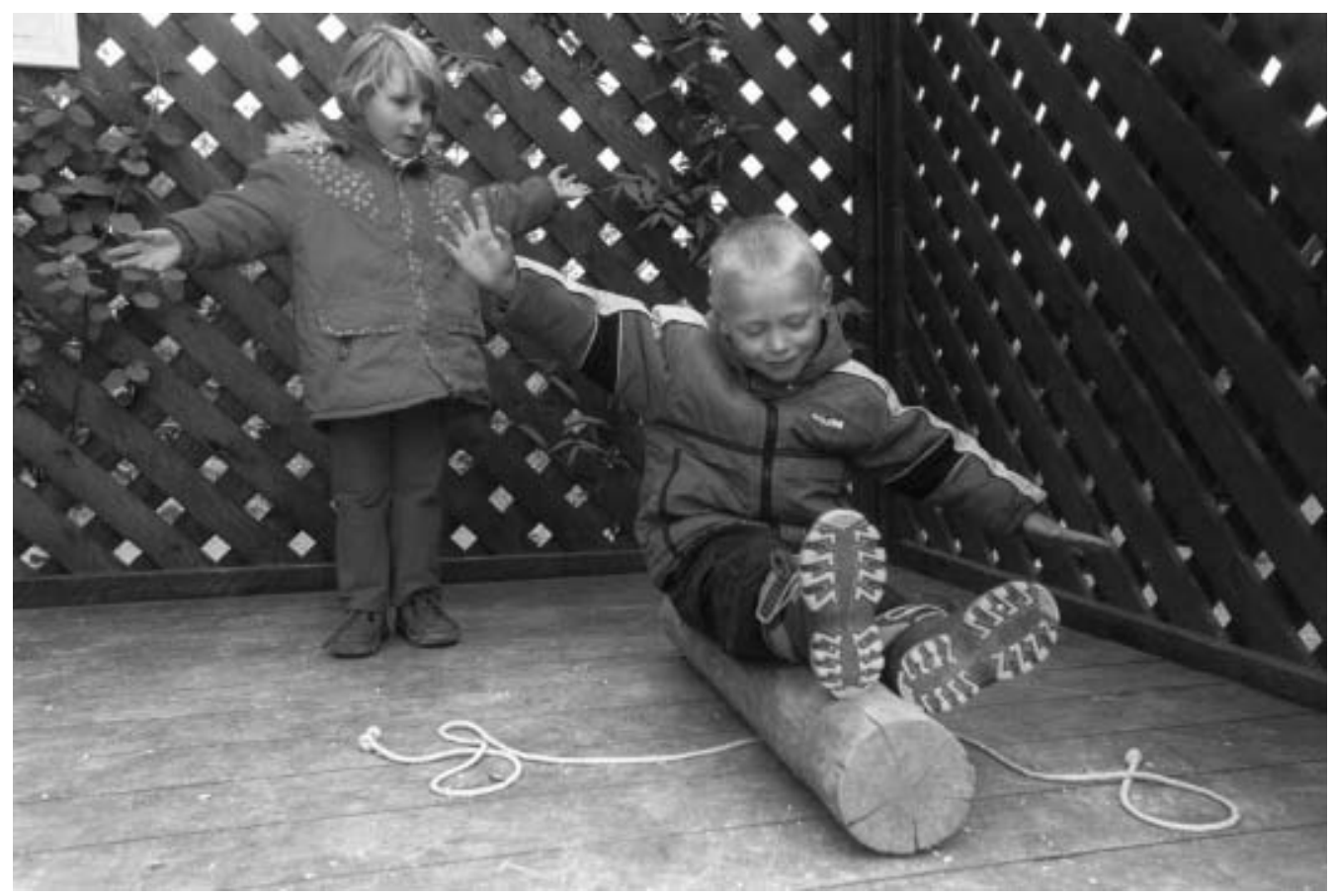

Narvaer 1. Foto: Niels Nyholm.

fysiske love, men også efter nedlagte instinkter med principielt forudsigelig aggression eller flugt, alt efter hvilke reflekser, hunden har indlært. Sparker man til et menneske, f.eks. i en fodboldkamp, vil de to første reaktioner finde sted, en lovmæssig og en refleksmæssig, men begge dele vil sandsynligvis blive overskygget af en tredje, nemlig den ramtes forsøg på en tolkning af intentionen: »Hvad f..... er meningen? Var det forsætligt eller uforsætligt? Kan situationen aftvinge frispark, hvis jeg falder skrigende om? Kan dommeren forføres til at uddele gult eller rødt kort? Eller får mit hold fordel, hvis jeg blot behersker mig og løber i position? Skal jeg tage imod en undskyldning, eller skal jeg planlægge en hævnakt for at sætte mig i respekt? «

I en sådan analyse vil der kunne peges på mange situationer, hvor individernes adfærdspotentialer og valg af positionering er stærkt bundet til - låst til - uomgængelige nødvendigheder i forhold til opretholdelsen af livet med arbejde, besværgelse af døden, kamp mod ydre trusler eller med psykiske og fysiske dispositioner som stærkt begrænsende vilkår. Men der gives også rum, hvor individet med større frihedsgrader kan forvalte sin eksistens. Skønt bundet til forplantningen og dermed til biologien udgør for eksempel erotikkens og kærlighedens kulturformer et sådant rum.

Specielt for den fænomenologiske antropologi er dog udpegningen af legens univers som et universelt, eksistentielt rum, hvor mennesket især kan transcendere sin egen tilværelse. J. Huizinga bestemmer mennesket først og fremmest som 
»Homo ludens «, det legende menneske, ${ }^{7}$ og Eugen Fink formulerer, hvad der kunne være et motto for den fænomenologiske antropologi: at leg ikke blot er et middel mod centrale forstyrrelser i det moderne menneskes tilværelse, men at leg er selve tilværelsens uforstyrrede centrum. ${ }^{8}$ Legen foregår dog ikke i fuldstændig ubunden frihed, for dels er der stadig rammebetingelser for legesituationen, dels eksisterer de $\emptyset$ vrige vilkår: arbejdet, kampens og $\mathrm{d} \varnothing-$ dens, side om side med legens mulighed, og endelig rummer den konkrete leg i sig selv i kraft af de regelværk, som indstiftes, og som individerne underkaster sig, sin egen begrænsning. Det særlige er imidlertid, at legen udpeges som eksistentiel kategori og for eksempel hverken som middel, restprodukt eller eskapisme i forhold til tilværelsens $\varnothing$ vrige grundvilkår. Leg udgør selv en eksistentiel, irreduktibel grundform, som man dog skal være forsigtig med at kalde et vilkår. I sin mangel på ydre hensigt og funktionalitet unddrager den sig i højere grad end andre eksistentielle kategorier det praktiske livs betingelser og forudsætninger. Frem for at tale om legen som et menneskeligt vilkår er det derfor mere præcist at kalde den en grundform, en kategori eller en modalitet, hvor meget er muligt og lidt er forudsat. Her adskiller Helmuth Plessner sig dog fra de $\varnothing$ vrige: I sin analyse af den specifikt menneskelige »ekcentriske « positionering i verden noterer han, at mennesket i modsætning til andre organismer er konstrueret således, at det er henvist til at lege. Menneskets bevidsthed er en selvbevidsthed, som indebærer en distancerende fordobling, hvor det distancerende jeg permanent har det distancerede jeg og dette jegs virkelighed $\mathrm{i} »$ spil«, og Plessner kalder denne fordobling legende og taler derfor om en »legetvang «, ${ }^{9}$ men det er en tvang, hvorunder det nye, det uforudsigelige, det overraskende kan opstå.

\section{Leg og padagogik}

Den fænomenologiske antropologis placering af leg som central selvgyldig virksomhed i menneskelivet adskiller sig fra den pædagogiske traditions opfattelse af leg, hvor man kan skelne mellem to syn på barndommens leg. Begge anskuer leg som et opdragelsesmiddel, men det er alligevel muligt at skelne mellem en funktionalistisk og en romantisk tradition.

Den funktionalistiske holdning til leg har rod i det 17. århundrede og formuleres af John Locke, ${ }^{10}$ der anskuer barndommen som en særlig læretid. Opgaven er at tøjle barnets naturlige energier og bringe dem ind i nyttige og dydige baner, hvor de med passende hensyntagen til barnets motivation og evner - kan omsættes til pligtfølelse, lydighed, renlighed, nøjsomhed og præcision, og hvor man også kan udnytte barnets naturlige nysgerrighed til at lære det flid, snilde og håndværksmæssige færdigheder. Det gælder med andre ord om at tæmme den unyttige og frie leg, men fastholde motivationen og den legende indstilling som middel til indlæring af dydige egenskaber og nyttige gøremål.

Den romantiske opfattelse af barndommen udvikles hen mod slutningen af det 18. århundrede i opgøret med absolutismen. Det gennemgående er, at alle træk, som fyrsten ikke har nogen ære eller andel i, bliver lovprist: følelsen, anelsen, myterne, historien og det overnaturlige, men også det naturlige $\mathrm{i}$ form af for eksempel den simple håndværker eller den ukunstlede malkepige. Især barndommen vurderes højt, idet det uspolerede barn anses for at stå nærmere naturen end de affekterede voksne, ødelagte som de er af det absolutte 


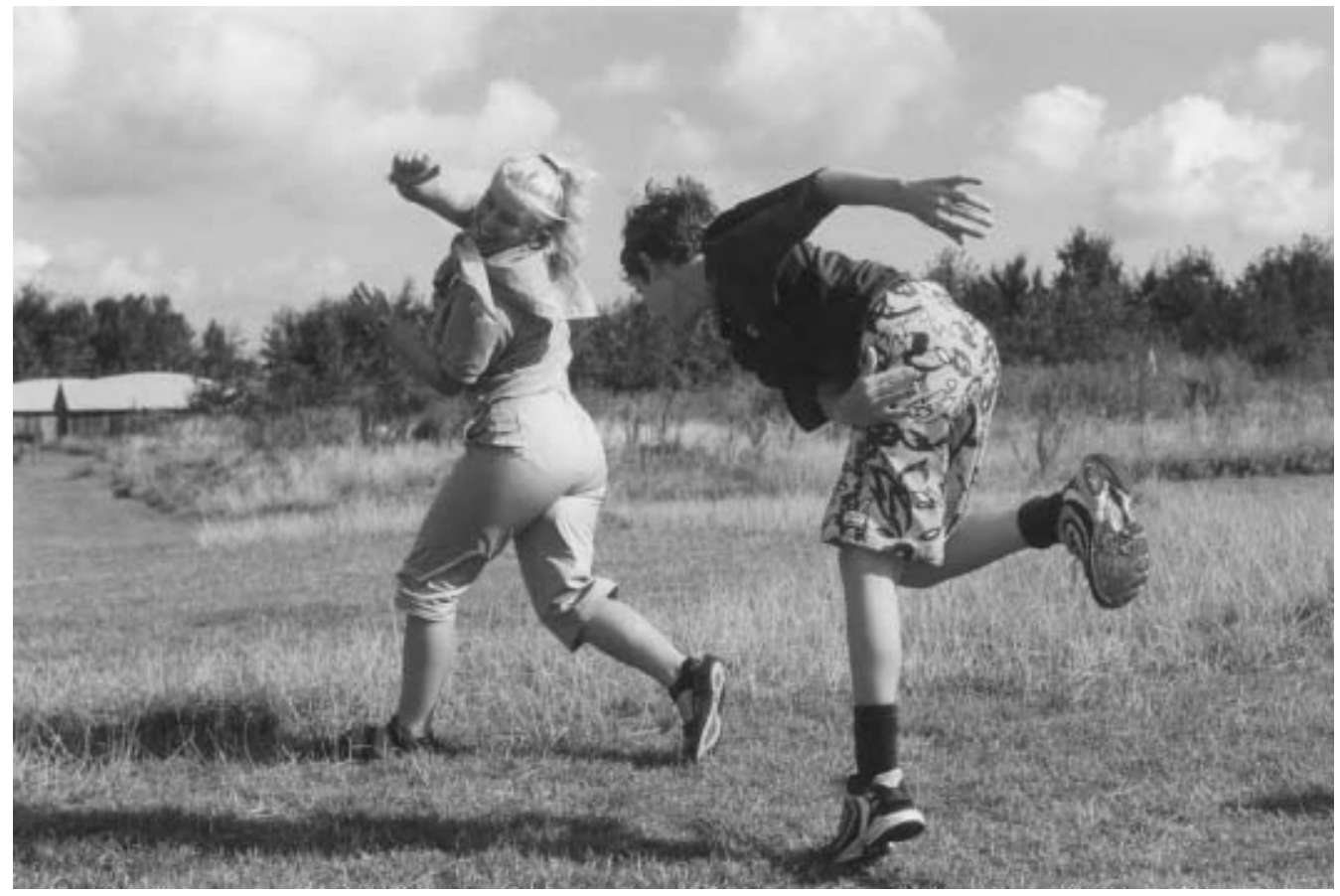

Narvaer 2. Foto: Niels Nyholm.

samfunds normer og standarder. Den pædagogiske konsekvens, som litterært bliver draget af J.J. Rousseau ${ }^{11}$, og som praktisk udmøntes af de tyske filantroper, er, at det først og fremmest er barnets selvvirksomhed i fri udfoldelse, som kan sikre dannelsen af ordentlige mennesker.

Skønt det romantiske og det funktionalistiske syn på børns leg kun er forenelige, hvis nytte og natur er identiske, hvilket sjældent er tilfældet, synes dette i reglen ikke at være noget problem for børnepædagoger, som udøver deres praksis ét eller andet lykkeligt sted mellem de to teorier, hvor måske også virkeligheden befinder sig: dels som genstand for forældremæssige forventninger og med tyrkisk tro på den ordnede legs læringseffekter, dels i romantisk værn om podernes egen særligt værdifulde og uantastelige kultur, der i reglen re- gistreres ved, at deres tegninger med pligtskyldig beundring hamres op på køleskabsdøren.

Står man i den sammenhæng over for et musikalsk vidunderbarn, en kommende ballerina, et fodboldtalent i svøb eller en mulig svømme- eller gymnastikstjerne, må man dog nok forvente at omgivelserne giver fanden i børnekulturen, som indskrænkes til netop det minimum, der kan legitimere, at man overhovedet har med børn at gøre, og sætter alle sejl i et rent funktionalistisk fors $\emptyset \mathrm{g}$ på at udvikle det talent, man måtte ane, til stjerne i en kommende voksenverden. Men mindre end stjernedrømme kan gøre det: Samlet kan f.eks. idrætsverdenen ses som en alvorlig konkurrent til - for nu ikke at kalde den et anslag mod børns egen kultur. Om idrætsverdenen så faktisk opelsker de kvalifikationer til vok- 
senlivet, der reklameres med, er en anden sag.

Helt galt står det dog ikke til: Den instrumentelle holdning til børns udvikling rummer - i det omfang den har succes, og $\mathrm{i}$ det omfang vi overhovedet behøver at tage den alvorligt - et kærligt hensyn til børns motivation og begejstring, mens selv det mest glødende forsvar for såvel barnenaturens som børnekulturens ukrænkelighed modificeres af håbet om, at de engang vil blive ordentlige mennesker.

\section{Fra udvikling til eksistens}

Det ligger i pædagogikkens ærinde, at den er udviklingsorienteret og middelbar. Hvad enten den er romantisk eller funktionalistisk, hvad enten den satser på fri eller ordnet udfoldelse, må den operere med en tilstand »før« og »efter« en pædagogisk indsats. Den er til syvende og sidst finalt orienteret, og argumenter for indsatsen er, at den fører til de ønskede mål. I det omfang, pædagogikken inkluderer leg i sit didaktiske projekt, må den derfor oftest skelne mellem gode lege og dårlige lege. Gode er de lege, der fremmer de ønskede mål, og de ses i skiftende tiders litteratur annonceret som nyttige eller dannende. ${ }^{12}$ For den romantiske orientering gælder det, at alle »naturlige « lege er af det gode, men vanskeligheden bliver så at skelne mellem »natur « og »unatur «. For begge pædagogiske retninger præges distinktionen mellem gode lege og dårlige lege, natur og unatur af de historisk skiftende mål for opdragelsen, og vanskeligheden ved at skelne bliver ikke mindre af, at »leg « på den ene side synes at være noget, enhver umiddelbart kender fra sig selv og véd, hvad er, mens eftertanken på den anden side viser sig at have uhyre vanskeligt ved at definere $» l e g «$.

Den fænomenologiske antropologi in- teresserer sig ikke for pædagogik. Dens ærinde er at forstå menneskelig praksis, og den hæfter sig ved det faktum, at vi alle har umiddelbare erfaringer med leg, hvorefter den placerer leg som et uafhængigt, irreduktibelt fænomen inden for det menneskelige adfærdsspektrum. Opgaven bliver så at bestemme betydningen af fænomenet leg som led i den menneskelige eksistens, og for denne opgave er definitionsfors $\emptyset \mathrm{g}$ om muligt mere presserende end for pædagogikken, men ikke mere enkle. Her kan der ikke skelnes mellem godt og skidt, naturligt og unaturligt. Definitionen må tage stilling til menneskelig leg i al sin mangfoldighed i enhver tænkelig forekomst.

Resultatet er et væld af forskellige meget komplicerede bestemmelser og definitioner, som demonstrerer, at fænomenologien, som netop er praksisforståelse, i sin egen praksis nærmer sig det uforståelige, hvilket ikke kan reduceres til en uheldig akademisk omstændighed (hvad det også er). ${ }^{13}$ I sine egne analyser forstår den nemlig godt, at det, som virker i det virkende liv, har simplicitetens, skønhedens og charmens karakter. ${ }^{14}$ Den véd, at den praktiske afgørelse af, hvad der er sandt, bevægende eller moralsk forsvarligt, afhænger af, at det, som fremstilles, er simpelt, skønt eller charmerende, og det er derfor selvophævende og selvmodsigende, at fænomenologiens legedefinitioner er komplicerede, uskønne og uden fortryllelse. ${ }^{15}$ De har i praksis ingen fremtid for sig!

Der skal derfor her fors $\varnothing$ ges en definition på leg, som måske ikke er skøn og charmerende, hvad andre under alle omstændigheder må være med til at afgøre, men dog i det mindste simpel og ligetil:

$$
\mathrm{P} / \mathrm{R}>1=\text { leg }
$$

Eller i klarsprog: 


\section{Hvis processen er vigtigere end resultatet, leger man!}

Samtidig afgrænser den sig i selve udgangspunktet fra arbejde:

$$
\mathrm{P} / \mathrm{R}<1=\text { arbejde }
$$

\section{Hvis resultatet er vigtigere}

end processen, arbejder man

Dermed findes straks en løsning på det væsentlige problem om forholdet mellem arbejde og leg, der ofte umiddelbart opfattes som gensidigt udelukkende, men hvor eftertanken har sværere ved at skelne. Definitionen betragter arbejde og leg som komplementære størrelser, hvor grænsen er subjekt- og synsvinkelafhængig. Legen kan vise sig endog yderst produktiv. Det spiller bare i situationen en underordnet rolle for den legende, og omvendt, hvis denne $\mathrm{i}$ en given situation oplever presset for at opnå resultater som det vigtigste, forvandles situationen fra leg til arbejde.

Mange legedefinitioner lægger vægt på, at leg er en uproduktiv aktivitet, men det er en polær måde at tænke på, som udspringer af det indlysende i, at mange former for arbejde bestemt ikke kan karakteriseres som leg, og eftersom sociale og $\varnothing$ konomiske definitioner af arbejde oftest hæfter sig ved arbejdets produktive karakter, sluttes modsætningsvist, at leg er uproduktiv. Dette giver mange vanskeligheder $i$ forbindelse med bestemmelsen af et væld af forskellige kreative aktiviteter og erhverv, som er produktive, men hvor det er svært at overse, at de rummer et legende element, ligesom også udsagn af typen »arbejdet gik som en leg « kræver særlige overvejelser i den sammenhæng. Det fordrer også en særlig anstrengelse at diskvalificere f.eks. konstruktionslegene, som direkte tager sigte på at bygge eller frembringe ét eller andet. Her bliver det nødvendigt at foretage et kunstgreb, hvor produktion og nytte sættes som identiske, hvorefter det for en overfladisk betragtning kan afgøres, at det, som frembringes i en konstruktionsleg, er uden nytteværdi og dermed uproduktivt. Mange lege er i det hele taget resultatorienterede: Der sættes i legen materielle eller immaterielle mål, som det gælder om at indfri, og indfrielsen kan være forbundet med ros, ære, respekt, prestige etc., alt sammen noget, som kan have enorm symbolsk værdi for den, som udøver legen eller på anden måde indgår i dens univers. Produktionen af sådanne værdier må helt fortrænges, hvis man i en definition binder sig til, at det uproduktive er et konstituerende træk ved leg.

Hvis man derimod gør forholdet mellem proces og resultat til hovedsagen, forsvinder det problem, at der i mange lege produceres ét eller andet, og der åbnes for en forståelse både af, at arbejdet kan have karakter af leg, og af at der i leg kan udføres et stykke arbejde.

Dermed ophæver definitionen også skellet mellem børneleg og voksenleg, men kaster samtidig lys over det. Når vi tror, børn leger meget mere end voksne, er det fordi, vi opfatter dem som uproduktive, hvilket de måske også er, set fra et voksensynspunkt eller et nyttesynspunkt. Omvendt, når legen er forbundet med forestillingen om manglende produktivitet, bliver det i en protestantisk voksenverden, hvor flid kan føre til frelse, nærmest syndigt at lege, hvorfor der hersker et udbredt legetabu, og hvor vi udsætter os for misbilligelse, hvis vi skulle komme til at indrømme, at vi går på arbejde, fordi vi i virkeligheden elsker denne sjove leg. For at sandsynligg øre, at vi er lønnen værd, forventes vi at skabe 
rammer, som regelmæssigt får os til at se jagede og lidende ud.

Definitionen afklarer ligeledes skismaet mellem leg og alvor, for der er intet til hinder for, at den agerende kan give sig hen $\mathrm{i}$ processen med den højeste grad af alvor, tværtimod. Men samtidig udtaler definitionsparret sig med stor klarhed om legens forhold til nødvendighedens rige: I takt med, at nødens alvor dominerer bevidstheden, forsvinder legen ud af den menneskelige praksis. At jødiske børn formåede at lege i Warszawas ghetto, i skyggen af død og elendighed, rokker ikke ved dette, men udtaler sig om den menneskelige evne, især børns, til med legen som overlevelsesmiddel at suspendere $\mathrm{n} \varnothing \mathrm{d}, \mathrm{d} \varnothing \mathrm{d}$ og tvang, og eksemplet viser derfor netop, hvor alvorlig en sag, leg kan være. ${ }^{16}$

Et andet skel, som mange legedefinitioner gør en del ud af, og som volder store kvaler, er skellet mellem virkelighed og fiktion. Det fremhæves, at leg ikke er rigtig virkelighed, men foregår i en art »som om «-univers, der er tydeligt for eksempel i børns legen far-mor-barn, mens det omvendt indebærer betydelige problemer at udpege »som-om《-universet i lege, med åbenbare konsekvenser for liv, helbred og fremtid. Den her anvendte definition ignorerer gennem sin fremhævelse af nærværet i processen dette skel. I nærværet bliver aktiviteten lige gyldig, lige »virkelig«, hvad enten universet er fiktivt eller ej. Faktisk er det kun i forhold til legens resultater og konsekvenser, at et virkelighedskriterium for alvor kommer i spil, og da definitionens indifferens over for det resultatmæssige er fastslået ovenfor, kan diskussionen af legens forhold til fiktion og fakta se bort fra denne dimension, og man undgår at skulle svare på, om atomfysikerens teoretiske manipulation med superstrenge er leg og mindre virkelig end feltherrens rokeringer med sine brigader eller skolebarnets konstruktion af huler i træerne.

Et sidste forhold, som hænger sammen med fiktionsdiskussionen, vedrører spørgsmålet om åbne eller lukkede regelsystemer, hvor det til forsvar for fiktionsargumentet fremhæves, at der indgås en art kontrakt om, at leg foregår i et særligt univers, eller at legens velkendte regler »automatisk « konstituerer sit eget lukkede univers. ${ }^{17}$ Dette vil ofte være tilfældet, og det spiller en betydelig rolle i definitionens påpegning af betydningen af at gå op i legen, at være nærværende $\mathrm{i}$ processen og dermed lukke forstyrrende forhold ude. Anskuelsen lukker imidlertid samtidig for en forståelse af legens komplicerede samspil med andre former for menneskelig praksis og er nødt til at overse, at leg er dybt integreret i de fleste aspekter af den menneskelige virksomhed. At lege kan være underkastet alle grader af formalisering fra det helt lukkede og stive regelsystem til den hemmelige, åbne og usikre overenskomst om, at »dette nok er en leg «, og skønt det måske kan forekomme monstrøst at nævne, har en hel del legeteori af gode grunde svært ved at benytte et fiktionskriterium til at diskvalificere krig og børsspil som leg, og omvendt acceptere ekstremklatring, bilvæddeløb og anden professionel sport. Her må forestillingen om lukkede regelsystemer og klare skel mellem »virkelighed « og fiktion give op. Med klare konsekvenser for muligheden for at anvende disse skel i en præcisering af, hvad leg er for noget.

\section{Når vi leger, det er vigtigt}

Et tilbagevendende problem i den fænomenologiske legeanalyse har bestået $i$ at bestemme legens forhold til sport, ikke mindst til præstationssporten i sin moderne 
version, og det bliver derfor et af artiklens hovedformål at afprøve definitionen på forskellige aspekter af dette felt. Et senere afsnit vil desuden beskæftige sig med legens komplekse grænseflader til det terapeutiske og det pædagogiske.

Både Plessner og Huizinga diskvalificerer sporten som leg, og også vores legedefinition må medgive, at moderne sport synes at være særdeles resultatorienteret og derfor ikke kan komme i betragtning som leg. Faktisk er resultatet et konstituerende element i præstationssporten. Hvordan skulle processen så kunne være vigtigere?

Her har Bernhard Suits ${ }^{18}$ en vigtig pointe, idet han peger på, at spil ikke konstitueres alene ved resultatet, men altid også ved valget af fremgangsmåder, som er hæmmende og besværlige. Formålet er ikke blot at vinde, men at vinde (eller indfri bestemte målsætninger) idet man underlægger sig begrænsende og regulerende regler, som flytter fokus fra endemålet til den tekniske udførelse - til bestræbelserne på at overvinde de forhindringer, som reglerne udgør, hvilket samtidig er en flytning af opmærksomheden fra det resultatmæssigt faktuelle til det æstetiske: Spillet skal være en nydelse, underholdende, fair, smukt etc. Hvis den tekniske beherskelse er virtuos, er det til at leve med, at der ikke bliver sat ny rekord hver gang.

I Tour de France er det for eksempel en begrænsning, at rytterne skal bruge noget så ineffektivt som en cykel og ikke en motorcykel, at de skal afholde sig fra doping, og, æstetisk set, at de skal demonstrere heroisme. I fodbold er der et begrænset antal legale måder at erobre bolden på. Hvis man blot skubber eller slår til modstanderen, eller andre ulovlige metoder tages $\mathrm{i}$ brug (og observeres af dommeren), vil der blive uddelt en passende straf. Men yder- mere er spillerne - i hvert fald på sigt nødt til at spille underholdende fodbold, og straffen for at bryde den regel vil være tilskuernes hån med de konsekvenser, den har for karriere og $\emptyset$ konomi.

Behovet for placeringer, penge og rekorder udgør dog altid indlysende tilskyndelser til snyd. Cyklen bliver næppe skiftet ud med en motorcykel, men der er mange andre muligheder for svindel, som unddrager sig kontrol, og som - hævdes det her - flytter opmærksomheden fra skønhed til effektivitet.

Fantasien kender ingen grænser, når det drejer sig om at omgå reglerne for at opnå større effektivitet end konkurrenterne, og forsøgene på at gøre det har ingen ende. Bevidst at bryde en spilleregel er imidlertid noget andet og mere end blot at begå en fejl. I samme grad som reglen er konstitutiv for spillet, er bruddet en nedbrydning af spillet og udgør en trussel mod det. Hvis man ikke spiller spillet (efter reglerne), spiller man slet ikke spillet (i praksis naturligvis afhængig af forseelsens størrelse, alvor og graden af overlæg, hvormed den udføres).

Hvis en bjergbestiger betjener sig af en helikopter for at nå toppen, kan man næppe sige, at han dyrker bjergbestigning, men mindre kan gøre det. De engelske udtryk "play the game « og »this is not cricket « anvendes bl.a. til intern selvjustits, men også i overført og udvidet betydning, og de griber det forhold, at regelbrud, også når det drejer sig om uskrevne eller æstetiske regler, truer selve spillet som spil, og de peger på en $\varnothing$ mfindtlig balance mellem regler og resultat, som antyder, at sejren ikke er alt, eller - med henvisning til definitionen på leg - at processen ikke er betydningsløs. 


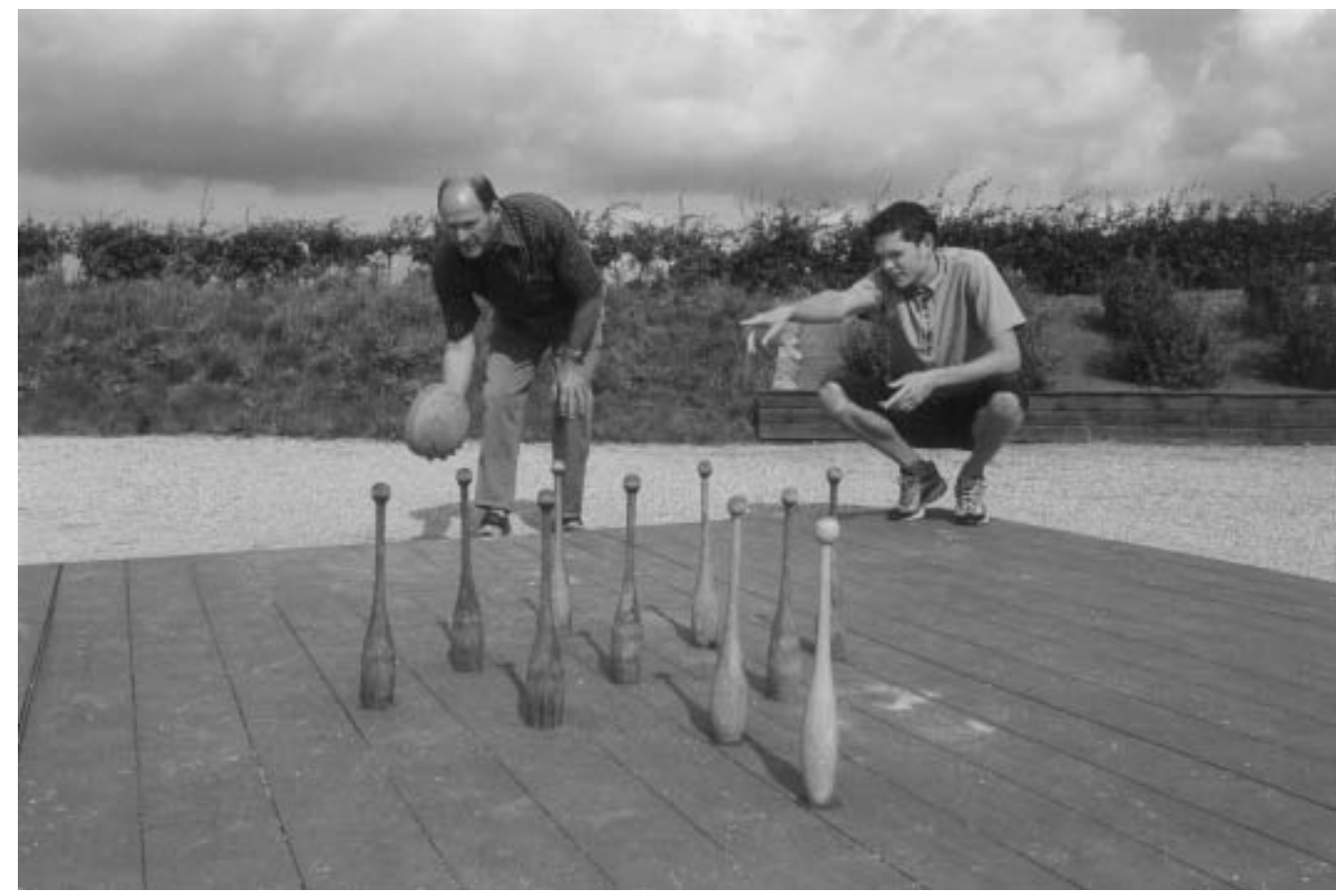

Narvaer 13. Foto: Niels Nyholm.

\section{Velfards-og fritidsidraet}

Når vi taler om kategorier som skoleidræt, breddeidræt, fritidsidræt og lignende, kan man hurtigt blive enige om, at resultaterne set i fugleperspektiv er ligegyldige. Hverken pressen eller det brede publikum interesserer sig for dem, end sige husker dem. Selv de implicerede har oftest glemt resultatet af en kamp efter et par dage. En serie interview med unge, som spillede basketball på beskedent niveau i regionale turneringer, afslørede, at drengene præcist kunne gøre rede for de enkelte holds placering, resultater og muligheder i turneringen. Pigerne derimod kendte ikke deres holds placering, ofte kunne de ikke huske, hvilke modstandere, de havde mødt, eller kampenes resultat, i mange tilfælde ikke engang om de havde vundet eller tabt. ${ }^{19}$ Under- søgelsen er af ældre dato, og forholdet kan udmærket have ændret sig. Ikke desto mindre retter de åbenlyse kønsforskelle opmærksomheden mod det forhold, at vigtighed og prestige er socialt konstrueret, og at virkeligheden for 20 år siden var konstrueret, så en sejr for en junior-dreng var af stor vigtighed og indebar betydningsfuld prestige, mens dette ikke var tilfældet for en jævnaldrende pige.

Man kan hævde, at den vægt, nogen lægger på sådanne resultater, er et spørgsmål om modenhed, og at drengene også efterhånden vil lære at sætte begivenhederne i deres »rette proportioner «, men det er næppe fair over for et enormt antal idrætsudøvere i de lavere rækker eller over for de stolte forældre, der weekend efter weekend slår kreds om boldbaner og svømmebassiner. Hvad er de »rette proportioner «? Er en 
kamp, hvor man er personligt involveret, måske ikke uendelig meget mere betydningsfuld end én, man ser på tv, uanset hvor meget man så ellers identificerer sig med heltene?

Idet vi holder fast $\mathrm{i}$, at den proces, som fører til sejren, er vigtigere end sejren selv, hvis begivenheden skal karakteriseres som leg, kan vi prøve at stille spørgsmålet: Hvad er det, man taber og hvad er det, man vinder, hvis man vil vinde for enhver pris? Hvordan måler og sammenligner man vigtigheden af henholdsvis resultat og proces, når vi har at gøre med størrelser, der er vage, subjektive og inkommensurable? Det er et svar, som må overlades til praksis, idet vi forventer, at en velintegreret person med sund dømmekraft i sin egen kontekst er i stand til at afgøre, om en idrætsbegivenhed er leg eller ej. Afgørelsen er ikke vilkårlig, men har at gøre med accepten af brud på skrevne såvel som uskrevne regler, kvalitativt såvel som kvantitativt i bestræbelserne på at realisere, hvad der er legens mål. Disse regler er som sagt ikke blot de nedskrevne, men vedrører også forventninger af mere uhåndgribelig natur: Gør spillerne deres bedste, udviser de den rette ånd og værdighed etc. De er knyttet til den helt individuelle følelse af begejstring eller frustration, men de er også kollektivt forbundet med en medleven og en evne til at identificere sig med andres fryd eller skuffelse, og ydermere udelukker afgørelsen af, om begivenheden er en leg, eller den er $»$ gået over gevind «, slet ikke, at det er en del af legen at lege, at resultatet er utrolig vigtigt, ja, faktisk det eneste, der betyder noget. Men hvis målet helliger midlerne, kan man ikke vinde i den pågældende leg, for så eksisterer den ikke mere.

Denne pointe kan sættes i yderligere relief, hvis man sammenligner med markedsøkonomien, hvor der også er spille- regler for produktionsprocessen, men hvor den færdige vare ikke mister sin værdi, uanset hvor mange regler der er overtrådt under dens tilblivelsesproces. Det er dette forhold mellem brugsværdi og symbolsk værdi, der er afgørende for legen. - Ikke at legen kun producerer symbolske værdier, men at produktionen af brugsværdier ikke korrumperer produktionsprocessen, hvad den altid tenderer mod at gøre i markedsproduktionen: fra håndværk til fabriksarbejde, fra unika til masseproduktion, fra rene til syntetiske råvarer etc.

\section{Elitesport}

Ved første blik synes en legedefinition at være uden relevans for professionel elitesport.

Elitesportsbegivenheder er kommercielle show-varer, som fører deres parasitære liv i dyb gæld til amatørsporten i de gode gamle dage, og de produceres af en hårdt arbejdende atletisk arbejdsstyrke, som udbyttes eftertrykkeligt i henseende til helbred, arbejdsvilkår og økonomi - det sidste dog med undtagelse af et par 1000 med stjernestatus.

Det er imidlertid kun en del af billedet. Megen professionalisme kan ikke betale sig. Mange topsportsdiscipliner er ikke spektakulære og får kun medieopmærksomhed hvert fjerde år, når de dukker op på det olympiske program. Mange sponsorer og klubejere taber masser af penge af kærlighed til deres sport, og når de bliver interviewet, erklærer sportsstjernerne gang på gang, at de stopper karrieren i samme øjeblik, de ikke længere synes, det er sjovt. Og det synes at være en glæde og kærlighed, som udspringer - ikke af deres triumfer, deres penge, og den prestige, de har opnået, men af glæden ved selve sporten. Man ser således professionelle fodbold- 
spillere, som fortsætter på amatørbasis, når karrieren er slut, eller som golfspillere, hvis de er for skadede. Professionelle sejlsportsfolk fortsætter som fritidssejlere, og cykelryttere forbliver turcyklister.

Det skaber et paradoks for vores definition: Eftersom elitefærdigheder ofte opnås gennem hårdt træningsslid, ensomhed, monotoni, afsavn og lidelse, må vi konstatere, at der er mennesker, for hvem dette på samme tid indebærer et endnu rigere mål af fornøjelse, spænding og måske endog leg, hvis definitionen skal passe, og det er jo interessant.

Det må indrømmes, at de virkelige motiver er svære at efterforske. Til billedet hører også $\varnothing$ konomisk og fysisk udbytning, begrænsninger i friheden, korrumpering gennem succes og uløselige dilemmaer vedrørende forholdet mellem helbred og resultater. Men generelt synes feltet domineret af motivation, engagement og glæde på trods af den kendsgerning, at ikke så få topatleter ville kunne opnå højere indtjening, tryggere vilkår og måske endda større prestige i andre karrierer. Vi må derfor konkludere, at en primær motivation til deltagelse i elitesport er af æstetisk karakter, hverken rationelt knyttet til hovedet eller moralsk til hjertet, men en smagssag, lokaliseret til maveregionen. - En følelsesmæssig binding, til selve sportsudøvelsen, som synes stærkere hos topatleten end hos den gennemsnitlige udøver for slet ikke at tale om tilskuerne, hvor hysteriet vedrørende resultater og mangel på respekt for det ædle i selve kappestriden forekommer langt hyppigere.

\section{Ekstremsport}

Når det drejer sig om ekstremsport, særligt de såkaldte high risk activities (HRAsports), hvor udøveren sætter livet på spil ud fra en kalkuleret risiko, bliver diskussionen af forholdet mellem proces og resultat endnu mere speget. Fra ét synspunkt kunne man hævde, at der ikke findes nogen form for leg, det er værd at sætte livet på spil for, hvilket betyder, at ligegyldigt hvad man foretager sig: Hvis man »leger« med sit liv, så er det ikke nogen leg. I henhold til definitionen må resultatet være af så afgørende betydning, at ingen proces, intet forehavende eller erfaring er vigtigere eller mere værdifuld.

Fra et andet synspunkt præsenterer ekstremsporten sin udøver for udfordringer og risici, som udgør konstante påmindelser om, hvor værdifuldt livet er. At lege med livet er selve essensen af leg - en manifestation af, at processen, det at leve ekstremt, udgør den højeste hyldest og værdsættelse af det faktum, at man har fået livet. At leve fuldt ud er at risikere livet!

\section{Leg som terapi}

Under en evolutionær, en terapeutisk eller en pædagogisk synsvinkel giver definitionen anledning til overvejelser. I disse kontekster må leg nødvendigvis anskues som et redskab eller en metode. Hvis leg skal have relevans, skal der være et formål med den, hvad enten dette formål er artens udvikling, fysisk og mental sundhed eller den individuelle tilegnelse af fysiske, psykiske og sociale kompetencer. Det kan godt være, at pædagogen eller terapeuten kalder en aktivitet for $» l e g$ «, men vedkommende arbejder samtidig med en skjult dagsorden vedrørende de resultater, »legen « skal afstedkomme. Leg er med andre ord et stykke arbejde, en træning, og hvis det er sådan, at aktiviteten også fra udøverens synspunkt udføres for resultaternes skyld, kan den være meget sjov i begyndelsen, men risikerer hurtigt at blive oplevet som tvang. 
Det er noget, man skal, hvis man skal klare sig, blive rask, dygtig eller et ordentligt menneske. Jo vigtigere målene er, jo mere ombrydes legen til hårdt arbejde.

Den legendes egen motivation til at lege er aldrig bevidst og primært fæstet til ønsket om at vokse op og overleve eller blive dygtig, sund og dannet. Disse kvaliteter kan i bedste fald betragtes som sidegevinster, men at de skulle indgå i en definition af leg, kan afvises ved at anføre et væld af modeksempler, hvor leg er alt andet end sund og dannende, og hvor sunde og dannende aktiviteter er alt andet end leg. ${ }^{20}$

Betænkelige er derfor tidens instrumentelle mantraer om »leg og læring «, »leg og kompetence «. Snarere end viden om legens begreb og muligheder er de symptom på pædagogisk afmagt i et skolesystem, som, trods sin målrettethed, har stadig vanskeligere ved at følge med eksplosionen i en faglig viden, der er mistænkt for at være forældet, inden ungerne forlader skolesystemet. Den stiller store krav til lærerne som altmuligmænd og fordrer af eleverne, at de skal kunne kunne, samtidig med at systemet er usikker på, hvilke metoder, der bibringer eleverne evnen til at kunne kunne. Når problemet kombineres med en vilje til at møde eleverne, hvor de er i praksis, subsidiært en afmagt over ikke at have autoritet til at kunne kræve at møde dem andetsteds, så bliver løsningen, at den pædagogiske institution forgriber sig på børnenes eneste friområde $\mathrm{i}$ et skolesystem, som efterhånden har besat hele barndommens og meget af ungdommens vågne tid.

Det betyder selvfølgelig ikke, at terapeutiske, udviklingsmæssige eller pædagogiske sidegevinster ved leg er uden relevans. Men det betyder, at leg uspecificeret og i sig selv ikke automatisk fører til disse resultater. Omhyggeligt udvalgt og organi- seret kan leg vel bruges som et redskab, der forhåbentlig afstedkommer visse nyttevirkninger. I hvert fald er fascinationen af leg ofte så stærk, at den instrumentelle brug vil få ofrene for terapeutiske strategier til at sluge mangen en bitter pille, uden at der derved gøres større skade.

\section{Friluftsliv og leg}

Men er det altid tilfældet? I friluftsliv synes aktiviteterne i højere grad at basere sig på forskellige modestrømninger, hvis legitimation efterrationaliseres, end på egentlig viden. Her er det grænseoverskridelse, som er det terapeutiske mirakelmiddel, der bruges som løsning på ethvert problem, børn med sociale vanskeligheder kan komme ud for. For mange af disse storbybørn må man formode, at skrækoplevelserne i en for dem fuldstændig ukendt natur lægges oven i vanskelighederne. Det er i hvert fald en overvejelse værd, om grænseoverskridelse lige præcis er metoden at anvende på børn fra miljøer, der er så fattige på ressourcer, at de personlige grænser formentlig allerede krænkes regelmæssigt. For en veltrænet ranger er leg og naturoplevelse næppe det samme som for en 12årig storbypige, og aktuel pædagogisk viden synes ikke at berettige rangeren til nogen form for skråsikkerhed, når det gælder om at vurdere børns robusthed og grænser. Hvad er barnets egen motivation, og hvad er ydre pres? Forskellen på en udfordring og en raffineret form for tortur kan være hårfin, hvis ikke aktiviteten finder sted under ubetinget frivillighed, og kun hvis processen i barnets eget perspektiv er den fascinerende del, er terapeutens arbejde berettiget til at bære navnet leg i stedet for tvang. ${ }^{21}$ 


\section{Sex}

Et sidste eksempel, som kan kalde på nogen refleksion over forholdet mellem proces og resultat, er sex. I et evolutionært perspektiv er sex en uomgængelig foreteelse, og mange former for tabu lader sig givetvis forklare som evolutionært praktiske: omgang med dyr, incest, homoseksualitet etc. En del tabuer må indskyde den private ejendomsret som forklarende mellemled: kravet om brudens uberørthed, kravet om familiedannelse, kravet om troskab etc., men måske stiller også disse restriktioner sig på historisk relevant måde i evolutionens tjeneste. I moderne vestlig kultursammenhæng er der imidlertid en masse mennesker, som kopulerer blot for fornøjelsens skyld og herunder ivrigt bestræber sig på at undgå at tjene evolutionen. De leger. Andre par ønsker sig måske inderligt et barn, men har ingen større succes med projektet, og som tiden går, kan de tænkes at tage alle mulige forskellige besværlige teknikker i anvendelse, med det resultat at fornøjelsen ved selve processen begrænses og afløses af hårdt arbejde. Evolutionær målrettethed er således nok en forklaring, men den giver ingen særlig indsigt i seksualadfærdens mangfoldige udtryk.

\section{Audens konklusion}

Hvad er det, som er så vigtigt ved legens ligegyldige resultater, at den synes at overskride enhver form for moral eller fornuft? Hvorfor er det så vigtigt at kaste sig ud i lege, der i reglen er så resultatorienterede, at det fuldstændig skjuler, at processen er den vigtigste? Hvad er det, som i virkeligheden er på spil?
I et essay fra 1948, »Squares and Oblongs $\ll,{ }^{22}$ giver W.H. Auden et temmelig kynisk svar, som ganske vist er møntet på æstetisk beskæftigelse i almindelighed, men som passer glimrende på leg og sport: »Det naturlige menneske«, siger han, »hader natur, og den eneste handling, som kan give det sand tilfredsstillelse, er den, som er omkostningsfri. I den finder mennesket en frihed fra nфdvendigheden på egne betingelser og efter egne regler «.

Auden skelner mellem to slags omkostningsfri handlinger: forbrydelsen og den »uskyldige« leg. I lighed med Suits finder han, at legens kvalitet skyldes følgende:

»Spillets regler g $\phi r$ spillet vigtigt, idet det dermed bliver vanskeligt, bliver en fardighedsprove. Men dermed rober spillene, at de $i$ realiteten er meningsløse, for det indebarer, at de kun er vigtige for dem, som har fysisk eller mentalt talent for at spille dem, og det er helt vilkårligt. Forudsat at en leg er uskyldig, er prøven på, om man bør lege den eller ej, simpelthen om man synes, det er sjovt eller ej, for jo bedre man er til den, jo sjovere synes man den er«.

En sådan adfærd, der må betegnes som rent æstetisk, finder Auden forklaringen på i en højst moralsk, stadig gentagen og foruroligende dagdrøm, der legalt kommer til udtryk i sætningen: »Hvorfor elsker min noste mig ikke for min egen skyld? « men som oversat til tavst tabu vil sige så meget som:

»Jeg elsker ikke min naste som mig selv, og må Herren se i nåde til min sjak «. 
1. Richard Schecherer, »The Future of Ritual. Writings on Culture and Performance (London, 1993, s. 27-29.

2. I flere af Platons værker, f.eks. Lovene, Statsmanden og Staten, betragtes leg som nødvendig for borgerlig dannelse og som et vigtigt udtryk for en persons karakter. I Lovene finder man metaforen om menneskene som gudernes legetøj, og i Staten findes den berømte huleallegori der fremstiller menneskene som deltagere i et marionetspil (360 f.Kr.).

3. Friedrich Nietzsche, Ecce Homo. Warum ich so klug bin (1888), »Når jeg beskæftiger mig med de væsentligste problemer, kender jeg ingen anden metode end legens (kap. 10).

4. Sprogspilsteorien er et gennemgående træk i Ludvig Wittgensteins tænkning, jf. »Nachlass« 115, Bog XI. Philosophische Bemerkungen.

5. H.G. Gadamer, »Der Begriff des Spiels« I: Wahrheit und Metode, vol. 1 (1960).

6. Michael Kolb, Spiel als Phänomen - Das Phänomen Spil - Studien zu phänomenologisch- anthropologischen Spieltheorien (Köln, 1989).

7. Johan Huizinga, Homo Ludens. Om kulturens oprindelse i Leg « (København, 1963 [1938]).

8. E. Fink, »Oase des Glücks« I: E.W. Gerber, »Sport and the Body«: The Ontology of Play (Philadelphia, 1972), s. 76-78. Finks betydningsfulde arbejder om legens fænomenologi retter sig blandt andet kritisk mod pædagogikkens syn på leg. Hans holdning til leg skal også ses på baggrund af, at han tilbragte flere år i koncentrationslejr under 2. Verdenskrig.

9. H. Plessner, »Spiel und Sport« I: Plessner et al., Sport und Leibeserziehung (München, 1967), s. 19.

10. John Locke, Some Thoughts concerning Education (Clarendeon Press, 1989 [1693]).

11. J.J. Rousseau, Emile eller om opdragelsen (1962) [1762].
12. Jf. J. Lauritzen, Underholdende og dannende Legemsфvelser for unger Mennesker (Odense, 1866).

13. Tilbagevendende problemer i fænomenologiens legedefinitioner er for eksempel vanskelighederne ved at foretage distinktionerne leg/alvor; leg/ arbejde; børnelege/voksenlege; dyreleg/menneskeleg; leg/ritual; leg/krig; leg/sport; leg som konkret aktivitet/leg som begreb; leg som konkret aktivitet/leg som symbol og metafor. Jf. også Eugen Fink Spiel als Weltsymbol (Stuttgart, 1960), s. 53-65.

14. Adskillige videnskabelige discipliner kan levere eksempler på teoremer og definitioner, som er simple, sk $\varnothing$ nne og charmerende og derfor anses for indlydende: Einsteins e $=\mathrm{mc}^{2}$; Marx's basis/overbygningsmetafor; Freuds overjeg/ego/id; Watson, Crick og Wilkins' dobbeltehelix; Pytagoras' $a^{2}+b^{2}=c^{2}$; Descartes' cogito, ergo sum etc.

15. Huizinga (1963).

16. George Eisen, Children and Play in the Holocaust. - Games among the Shadows (Amherst, 1988).

17. James P. Carse, Finite and Infinite Games $-a$ Vision of Life as Play and Possibility (The Free Press, 1987).

18. Bernard Suits »What is a Game?«I: Philosophy of Science, vol. 34 (1967).

19. J. Kempf, J. Møller og S. Riskjær, Idrcet og holdning 15-19 årige og 40-49 årige i tal og tale (Bavnebanke, 1983), s. 77.

20. J. Møller, »Idrætslege - træning eller kultur?« I: Kompetence og demokrati (Herning, 2000).

21. J. Møller, Forsvarlige Koblinger? - eller en polemik om idrattens kvaliteter (Idrætsforsk., 2000), s. 1-3.

22. W.H. Auden, »Squares and Oblongs« I: Poets at Work. Citeret efter J.S. Bruner et al., Play - Its Role in Development and Evolution (Penguin, 1976), s. 638-640. 